\title{
Reindeer husbandry/hunting in Russia in the past, present and future
}

\author{
Leonid M. Baskin
}

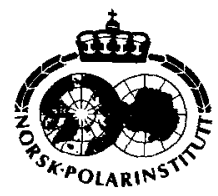

\begin{abstract}
The dynamic state of reindeer husbandry in northern Russia during the 20th century was studied as a basis for predicting the consequences of the current drastic changes taking place there. Similar forms and methods of reindeer husbandry were used with different frequencies and effectiveness throughout the century. In the future reindeer husbandry will conform to market requirements, landscape features and national traditions. In some areas, the more sophisticated methods of management developed in conjunction with large-scale, highly productive reindeer husbandry, could be lost and a subsistence economy, including hunting, could predominate.
\end{abstract}

L. M. Baskin, Institute of Ecology and Evolution, 33 Leninsky Prospect, Moscow 117071, Russia.

Since 1991, in the Russian North, social and economic reconstruction of the rural economy has had a strong impact upon reindeer husbandry. By the 1980s, in northern Russia, reindeer husbandry was highly productive (2.3 million domestic reindeer produced for consumption; 41.9 thousand tonnes live weight). A steep decline occurred in the 1990s, and at present in Russia there are ca. 1.6 million domestic reindeer. In Chukotka (see Fig. 1) their numbers declined from 500000 to 130000 , and large declines were observed in Evenkiya, Yakutiya and Kamchatka. Only in Yamal has significant growth of the reindeer population taken place in response to market requirements from the gas and oil industry development (Khrushchev \& Klokov 1998). These events are important for the human population of northern Russia (about 12 million) of which about 130000 belong to minorities who are closely connected with exploitation of reindeer as an important food and fur resource.

This paper's aim is to evaluate the ecological and social consequences of ongoing changes in reindeer husbandry. I take as a starting point for my predictions the study of reindeer husbandry development during the last century. It is observed that

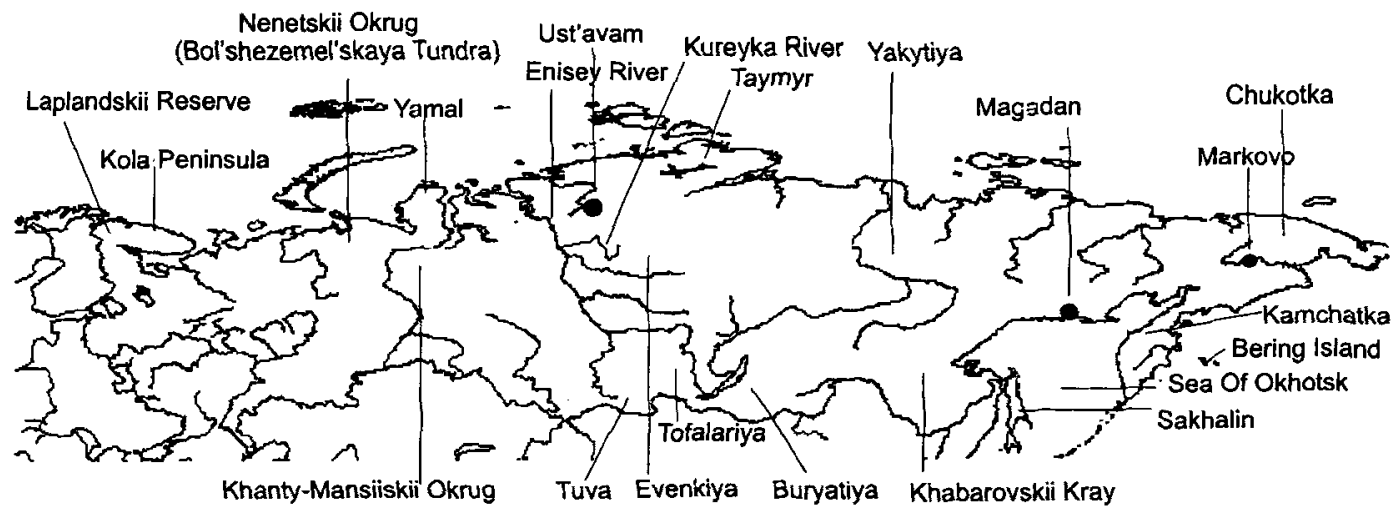

Fig. 1. Localities mentioned in the paper; settlements are marked 
the same principal features have occurred in different times and areas (Baskin 1991). The drastic changes occurring in reindeer husbandry in recent years will probably lead to situations that have occurred in the past. In addition, I point out that the reindeer is one of the few species whose domestication could occur without taming and while the species is also being hunted (Baskin 1974; Hudson 1989). All types of reindeer hunting and husbandry can be practised along a "procurement-production" gradient (Hudson 1989). Sophisticated methods of hunting, when humans used knowledge of migratory routes as well as directing reindeer herds to stone traps or to human settlements (Spiess 1979; Skogland 1989), were the first stages of husbandry. Control of reindeer in husbandry is based on aboriginal peoples' traditional knowledge of pastures, reinforcing herding behaviour and regulation of feeding. I suggest that any future changes in the human-reindeer relationship, even the replacement of husbandry by hunting, will remain on the same procurement-production gradient and will use the same methods of management.

The main advantage of reindeer husbandry, in comparison with hunting, is the possibility it provides for harvest at any moment; to have a guarantee of labour and survival. History gives us plenty of tragic examples of famine and extinction of hunting indigenous peoples, but prosperity of people who have husbanded reindeer (Vdovin 1965; Gurvich 1982). For northern Eurasia, fluctuations of wild reindeer numbers have a periodicity of 115-130 years (Krupnik 1975). Now, when the possibility of a complete crash of reindeer husbandry exists, we need to consider whether is it theoretically possible to exchange husbandry with hunting of wild or feral reindeer.

By the 1930-40s, political reforms were instituted to establish large-scale, maximum production husbandry under the management of state bureaucrats. To attain high productivity, the experience of native herders, as well as scientific knowledge, were used. In this paper, I shall review the most important methods of reindeer husbandry intensification and consider their prospects.

\section{Comparing features of reindeer husbandry in different areas and periods}

The main social event in reindeer husbandry in the $1930-40$ s was the alteration of property rights.
State managers followed communist doctrine, which aspired to eliminate rich owners, to unite small owners, and to arrange for maximum state control. Large properties were expropriated (sometimes purchased) and incorporated into state farms. Small-scale owners were united into cooperative farms (kolkhoz), which were also under the supervision of state authorities. On many occasions the same individuals, families or groups of families became the staff of new state or kolkhoz farms, and therefore managed the same animals which had been their property only a year before. Currently we observe the opposite process in the privatization of herds. Herders deprived of state control and subsidies use the animals for their own needs. In Soviet times private persons also owned reindeer, which comprised up to $10 \%$ of the total number of state and kolkhoz animals. D. Khorolia (pers. comm.) suggests that the modern growth of Nentsi reindeer husbandry in the Yamal and Bol'shezemel'skaya Tundra is an example of the rapid development of private properties.

Throughout the 20th century, different systems of management were used. "Close" herding, defined as keeping reindeer in big herds, was the main technique in the tundra and forest-tundra zones of Bol'shezemel'skaya Tundra, Yamal, Taymyr, Yakutiya, Chukotka and Kamchatka. The "free-camp" system, in which reindeer are kept in the vicinity of human settlements or camps, was used in Tofalariya, Tuva, Buryatiya and Sakhalin. "Loose" herding, in which herders only periodically gather scattered animals and move them to fresh pastures, was practised on the Kola Peninsula and in Khanty-Mansiiskii Okrug, Yakutiya and Evenkiya. In some areas, two or more methods were used. For example, on the Kola Peninsula there are two distinct indigenous traditions. Saami employ loose herding in winter, very strictly control females during the calving season, and release reindeer during the summer period. They gather reindeer in large herds again after the rutting season. Komi people use close herding year round. Their technology provides better results than the Saami method. However, attempts of Soviet authorities to force Saami to use Komi technology were not successful. In a few areas, reindeer are maintained in fenced enclosures (Kola Peninsula, Yakutiya, Khabarovskii Kray) but the high costs of this method limit its feasibility.

Keeping reindeer in large herds occurred in all periods but with different frequency. Since the 1940 s, each state or collective farm (kolkhoz) 
Table 1. Variations in the proportion of herds of different sizes under early development of reindeer husbandry in the Soviet Union, expressed as percent.

\begin{tabular}{lccccccc}
\hline & \multicolumn{7}{c}{ Total number of animals in a herd (\%) } \\
\cline { 2 - 8 } & Years & $<50$ & $51-100$ & $101-300$ & $301-500$ & $501-1000$ & $<1000$ \\
\hline Yamal & 1929 & 64 & 15 & 17 & 4 & 0 & 0 \\
Chukotka & $1937-38$ & 32 & 24 & 22 & 9 & 7 & 6 \\
N. Kamchatka & 1933 & 66 & 19 & 13 & 1.7 & 0.3 & 0 \\
\hline
\end{tabular}

possessed about 7000-20 000 animals divided into herds of 1000-2500 animals. These herds were managed by teams of 5-6 herders and 1-2 cooks (usually wives of herders) which received a salary from the farms. Herds were rotated along seasonal routes which were determined by pasture utilization plans developed for each farm.

Before the 1930s, in tundra areas there were a few large family-owned herds, with a maximum of up to 8000 animals (Table 1). Isaev (1935), Anonymous (1939), Shmit (1939) and Ustinov (1956) pointed out that small herds were not able to roam independently and thus their owners united to have at least a hundred animals in each herd. Behavioural research (Baskin 1974) demonstrated that the minimum herd size available for human management is 35 . For herding, the optimal size is $100-300$ animals, whereas the maximum herd size is $1500-3000$ animals (excluding newborns) because larger herds become fragmented.

Prior to the socialist reconstruction, regular and fairly remote routes of migration were typical only for the herds of rich owners (Isaev 1935; Razdelishin 1938, 1940). Those routes usually remained unchanged and were later used by state and kolkhoz farms. Small-scale owners occupied inland areas and moved more or less chaotically, often staying more inside certain restricted areas than following planned routes. Migratory routes often depended on involvement of herders in other activities (harvesting marine animals, fishing, hunting, transporting loads). For example, all inhabitants of the vast treeless areas of Taymyr (Nganasans, Dolgans, Nentsi) in the past, as well as nowadays, adjust their routes in late autumn to the forest line in order to collect firewood for heating. Inhabitants of coastal areas moved from the sea not further than $40-60 \mathrm{~km}$ (in winter) in order to be back near the sea in early summer when the sea mammal hunting season begins (Kopylov 1932; Anonymous 1945). These short "circles" of migration were mostly conserved in Soviet times, when reindeer herds inhabiting coastal zones were the property of kolkhozes whose main activities were fishing and sea mammal harvesting.

Herd size, animal distribution within pastures, speed of pasture rotation and methods which herders use to keep animals under control all strongly depend on landscape features, e.g. whether it is forest or tundra zone, narrow pasture (along canyons) or broad pasture (in flat, monotonous tundra) (Baskin 1970).

\section{Growth of productivity}

Organizers of socialist reindeer husbandry aspired to develop highly productive husbandry. To my knowledge, there was a shortage of scientific knowledge of reindeer husbandry at that time. However, the organizers of the state and kolkhoz farms made extensive use of indigenous knowledge. They made estimations of the carrying capacity of pastures and used these data to plan the growth of domestic reindeer numbers (Ivanov 1941; Razdelishin 1938, 1940). They observed that significant portions of small herds were sledge and riding reindeer and that even some females were used for transport. Production derived from small herds was either used by the owners or sold in rural markets. Only the large herds of rich people provided significant commodity production. The policy of increasingly large herds was accepted by the organizers of reforms. Organizers also determined that productivity is dependent on the proportion of females in a population. A high level of barrenness was found to be connected with biased male/female ratios (Table 2). According to the state standard later accepted in the USSR, the herd sex ratio must be one 3-year-old bull per 18 females and one $\geq 4$-year-old bull per 20 females (1:18 on average) (Borozdin et al. 1977).

Dividing herds before calving season into female and male portions, which was in the past done only by rich owners, had also become a 
Table 2. Characteristics of reindeer husbandry in the Russian North in 1935.

\begin{tabular}{|c|c|c|c|c|c|c|}
\hline Area, locality & $\begin{array}{l}\text { Native } \\
\text { groups }\end{array}$ & $\begin{array}{c}\text { Total human } \\
\text { population }\end{array}$ & $\begin{array}{l}\text { Reindeer } \\
\text { per holding }\end{array}$ & $\begin{array}{c}\% \text { of } \\
\text { females } \\
\geq 2 \text {-years }\end{array}$ & $\begin{array}{c}\% \text { of bulls } \\
\text { used in } \\
\text { breeding }\end{array}$ & $\begin{array}{c}\% \text { of } \\
\text { castrated } \\
\text { bulls }\end{array}$ \\
\hline \multicolumn{7}{|l|}{ Taiga zone } \\
\hline Evenkiya: & Kety, & & & & & \\
\hline Kureyka River & $\begin{array}{l}\text { Evenks, } \\
\text { Sel'kupy }\end{array}$ & 140 & 13 & 30 & 2.8 & 23 \\
\hline \multicolumn{7}{|l|}{ Magadan: } \\
\hline $\begin{array}{l}\text { Sea of Okhotsk } \\
\text { shore }\end{array}$ & Evens & 2154 & $26-58$ & 40 & 3.6 & 32 \\
\hline \multicolumn{7}{|l|}{ Tundra zone } \\
\hline Taymyr: & Nentsi, & & & & & $26-43$ \\
\hline $\begin{array}{l}\text { Mouth of } \\
\text { Enisey River }\end{array}$ & $\begin{array}{l}\text { Yuraki, } \\
\text { Dolgane, } \\
\text { Evenki }\end{array}$ & 2627 & $19-124$ & $31-40$ & * & \\
\hline Ust'Avam & Nganasans & 450 & 117 & * & * & * \\
\hline $\begin{array}{l}\text { Chukotka: } \\
\text { Markovo }\end{array}$ & $\begin{array}{l}\text { Chukchi, } \\
\text { Evens }\end{array}$ & $*$ & 117 & $46-77$ & $1.5-5.5$ & 22 \\
\hline
\end{tabular}

*No data.

routine obligatory activity in all state and kolkhoz farms. In the reindeer husbandry of Chukotka and Kamchatka, managing herds with the assistance of dogs became a common practice. In the past, herders of these areas had not used reindeer dogs. Plenty of these useful helpers were transported from the Nentsi region to the eastern regions. Among other innovations introduced in Soviet times were salt supplies for reindeer, permanent and transportable corrals, radio communication, provision of food and other necessities to the herders by airplanes, helicopters or tractors, and field huts equipped with iron stoves and sometimes synthctic covers. As a result, reindeer farms attained high productivity (Table 3 ).

\section{The future}

I predict two possible future scenarios. 1) The more optimistic one predicts preservation of the modern situation when a number of large farms established under the former USSR were supplemented by a number of small farms. The total number of reindeer, should this system prevail, will be stabilized at the level of local requirements for meat and skins, and ownership of animals will be partly changed because of the conversion of state farms into either cooperative farms or private herds. 2) The more pessimistic scenario predicts that productive reindeer husbandry will be preserved only in areas with optimal conditions for large herd husbandry and with more developed cultures of reindeer management (Nenetskii Okrug and Yamal, Yakutiya, Chukotka, Kamchatka). However, in the taiga zone and in areas with high numbers of wild reindeer, domestic reindeer herds will be preserved only in some localities where they will serve more as sources of transport reindeer than of meat and skins. Some families

Table 3. Maximum survival, calf production and meat production achieved at selected state reindeer farms of the Russian North.

\begin{tabular}{lcccc}
\hline Area & Year & $\begin{array}{c}\text { Animals survival } \\
\text { rate (\%) }\end{array}$ & $\begin{array}{c}\text { Calves per 100 } \\
\text { females }\end{array}$ & $\begin{array}{c}\text { Meat production } \\
\text { (100 kg per 100 animals) }\end{array}$ \\
\hline Nenetskii & 1949 & 93 & 82 & $*$ \\
Yamal & 1962 & 92 & 67 & 5.4 \\
Evenkiya & 1944 & $84-90$ & $67-68$ & 14.3 \\
Yakutiya & 1975 & 91 & 69 & 22 \\
Chukotka & 1989 & 89 & 67 & 19.7 \\
Kamchatka & 1960 & 99 & 93 & 32.0 \\
\hline
\end{tabular}

*No data. 
will preserve domestic reindeer in localities where the successful hunting of wild reindeer is not guaranteed.

The experience of the drastic growth of the reindeer population of Yamal provides evidence of the significant influence of gas and oil development. There, the strong market for meat coupled with significant financial assistance resulted in peak productivity prior to the collapse of subsidies. Unfortunately, overgrazing of the pastures of Yamal occurs now as a result of chaotic reindeer husbandry development (M. Okotetto, pers. comm.).

Even highly productive farms need subsidies from the state. In Soviet times the state deliberately paid significant additional sums for the produced meat so that income was sufficient to cover the expenses of salary, transport, communication, field tents and cloth. The same situation exists today in some regions. For example, in his 1996 decree the Chukotka governor, A. Nazarov, presented significant subsidies for all meat produced by reindeer farms (Nazarov 1996). According to the calculations of Khokhlenkov (1998), in Chukotka the cost of $1 \mathrm{~kg}$ of produced meat is 8 USD but the market cost is only 2.5 dollars. Expenses for venison production include $12 \%$ for salary, $6 \%$ for transport and fuel, and $21 \%$ for corrals and field huts. The cost of dead and lost animals is $61 \%$ of total expenses. The latter expense was, in Soviet times, three times less.

Maintenance of more complicated, highly productive methods of herding and hunting requires increased investments and labour, more sophisticated management and highly qualified herders, and better personal discipline among herders. As an example, a delay of only one week in the departure of a reindeer herd from winter grounds towards calving grounds will be followed by a chain of unfortunate events: the herd will not be able to cross large rivers on ice; it will arrive in summer pastures too late, when fresh vegetation will become scarce; the animals will suffer from insect harassment; the development of calves will be delayed, as well as the fattening of adult animals; the chances of hoof disease will increase; lean reindeer will suffer during the following winter; and calving in the next spring will suffer because of lean females will give birth to weak calves.

Hunting wild reindeer was always an important part of the subsistence economy. The low numbers of wild reindeer in the first part of the 20 th century stimulated the development of reindeer husbandry as a more reliable mode of production. Before the 1930s, in Taymyr, Nganasans used domestic reindeer more for transport than as productive animals. They were compelled by Soviet authorities to become more dependent on reindeer husbandry. However, in the 1970s, when the harvest of wild reindeer became the most important activity, Nganasans willingly returned to their traditional way of life. The same was true of the Evenks in Evenkiya (Anonymous 1945; Savel'ev 1971). In future subsistence economies wild reindeer will occupy a much more important position than in previous times.

A decline in the number of domestic reindeer may stimulate the growth of wild reindeer populations on recently freed pastures. The Taymyr population of 600000 wild reindeer and the Wrangel Island population of 3000 feral reindeer have been harvested since 1993 only on a small scale. However, observations from these areas during 1993-98 have not provided evidence of significant growth of these populations. In northern Eurasia we know of only two examples of reindeer declining as a result of population crashes. This occurred twice with Bering Island's population of feral reindeer (Abolits 1987). Another example, more disputable, was given by Semenov-Tien-Shanskiy (1989) for the Laplandskii Nature Reserve. Thus, we have few observations upon which to predict a catastrophic growth of wild reindeer populations.

Unique features of particular indigenous herding traditions as well as local ecological conditions must be considered to provide a sound prognosis. For some natives (Komi, Nentsi, Yakuts, Chukchi, Koryaks), commodity reindeer husbandry is traditional. For others, such as Nganasans, Evens and Evenks, who are more deeply involved in hunting and fishing, reindeer husbandry is only a subsidiary activity. Yet in Soviet times these peoples were compelled to develop commodity reindeer husbandry. In areas inhabited by these natives which experienced a decline in reindeer husbandry, the return of the people to hunting and fishing occurred quickly.

Among Chukchi and Koryaks the division between coastal and inland populations is well known. Coastal inhabitants showed more inclination to harvest sea mammals and fish than to breed reindeer. The same situation existed in Soviet times; reindeer husbandry in coastal areas primarily served the local market for meat and skins. At 
present, coastal reindeer husbandry in Chukotka has almost completely declined, but inland husbandry has survived. Sooner or later the situation of the 1930s may again be repeated: inland husbandry will produce meat and skins for consumption in coastal settlements, receiving in exchange necessary goods.

\section{Conclusion}

Reindeer is the most important biological resource of the North and the different ways it is exploited will not be abandoned but will undergo major changes. However, dependence on state subsidies can lead to the degradation of traditional indigenous economies. Among the various forms of reindeer exploitation, hunting wild or feral reindeer will remain important for subsistence economies and the rural market. In some areas (Taymyr, Yakutiya) hunting may provide meat and skins for a market provided by fishermen, miners, and military settlements. In the areas where there are few wild reindeer, the existence of such markets will stimulate the conservation of large-scale reindeer husbandry. Cultural traditions of the native peoples of northern Russia will also contribute to the conservation of reindeer husbandry. The drastic decline of husbandry in some areas may lead to the loss of technology necessary for highly productive husbandry. Scientific description of the indigenous practices and beliefs associated with reindeer herding, combined with its publication in both technical and general books, will be necessary to preserve indigenous culture for future generations.

\section{References}

Abolits, A. S. 1987: Istoriya vozniknoveniya i perspectivy eksploatatsii populyatsii severnykh oleney na ostrove Barentsa. (History of the establishment and perspectives on the exploitation of the reindeer population on Barents Island.) In V. E. Sokolov (ed.): Ratsional'noe prirodopol'zovanie na Komandorskikh ostrovakh. (Efficient utilization of natural resources in Komandorskie islands.) Pp. 144-146. Moscow: Moscow University Publ.

Anonymous 1939: Ekonomicheskiy ocherk basseyna reki Anadyr' Chukotskogo natsional'nogo okruga. (Economic overview of the Anadyr' River Basin in Chukotka National Okrug.) Central State Archive, fond A-310, opis' 18, delo 332.

Anonymous 1945: Materialy pervonachal'nogo zemleus- troystva Avamskogo rayona Taymyrskogo okruga Krasnoyarskogo kraya za 1934-1935 gody. (Data on preliminary land use organization in Avam Rayon, Taymyr Okrug, Krasnoyarsk Kray, 1934-1935.) Central State Archive, fond A-310, opis' 18, delo 67.

Baskin, L. M. 1970: Severnyi olen'. Ekologiya i povedenie. (Reindeer. Ecology and behaviour.) Moscow: Nauka Publ.

Baskin, L. M. 1974: Management of ungulate herds in relation to domestication. In V. Geist and F. Walther (eds.): The behaviour of ungulates and its relation to management. Vol. 2. IUCN Publ., New Ser. 24, 530-541. Morges, Switzerland. Int. Union for the Conservation of Nature.

Baskin, L. 1991: Reindeer husbandry in the Soviet Union. In L. Renecker \& J. Hudson (eds): Wildlife production: conservation and sustainable development. Pp. 218-26. Fairbanks: University of Alaska.

Borozdin, E. K., Vostryakov, P. N. \& D'yachenko, N. O. 1977: Razvedenie oleney. (Reindeer breeding.) Krasnoyarsk: Krasnoyarsk Publ.

Gurvich, I. S. 1982: Yukagiry. (Yukagirs.) In A. P. Okladnikov (ed.): Etnicheskaya istoriya narodov Severa. (Ethnic history of northern peoples). Pp. 168-179. Moscow: Nauka Publ.

Hudson, R. J. 1989: History and technology. In R. J. Hudson et al. (eds.): Wildlife production systems. Economic utilization of wild ungulates. Pp. 11-27. Cambridge: Cambridge University Press.

Isaev, V. Y. 1935. Otchet po obsledovaniyu olenevodstva $i$ sobakovodstva na polyarnoy stantsii mysa Shmidta. (A study of reindeer husbandry and dog breeding in the area around the station Mys Shmidta.) Central State Archive, fond A-310, opis' 18 , delo 88.

Ivanov, P. 1941: Zemleustroistvo rayonov Severnogo poberezh'ya Okhotskogo morya za 1935-1940 gody. (Land use organization of the northern shores of the Sea of Okhotsk, 1935-1940.) Central State Archive, fond A-310, opis' 18, delo 488 .

Khokhlenkov, V. 1998: Okhota na severnogo olenya. (Hunting of wild reindeer.) Krasnyi Sever 4, 4.

Khrushchev, S. A. \& Klokov, K. B. 1998: Nenetskoe olenevodstvo: podkhody $\mathrm{k}$ razrabotke kontseptsii ustoychivogo razvitiya (Nenetski reindeer husbandry: approaches to developing a concept of sustainable use.) Etnogeographicheskie i Etnoekologicheskie Issledovaniya 7, 1-47.

Kopylov, I. P. 1932: Ocherk khozyaistvennoy deyatel'nosti tuzemnogo naseleniya Dudinskogo rayona. (Outline of the economic activity of the native population of Dudinka Rayon.) Central State Archive, fond A-310, opis' 18, delo 21.

Krupnik, I. I. 1975: Prirodnaya sreda i evolutsiya tundrovogo severnogo olenevodstva. (Natural environment and evolution of tundra reindeer husbandry.) In S. A. Arutyunov et al. (eds.): Karta, skhema i chislo v etnicheskoy geografii. (Map, diagram, and figure in ethnic geography.) Pp. 26-43. Moscow: Moskovskii filial Geograficheskogo obshchestva SSSR (Moscow Dept., USSR Geographical Soc.).

Nazarov, A. 1996: Mery po stabilizatsii sel'skogo khozyaistva Chukotskogo autonomnogo okruga v 1966. (Steps to stabilize agricultural husbandry in the Chukotka Autonomous Okrug in 1996.) Kraynii Sever 119, 5.

Razdelishin, L. 1938: Plan 3 pyatiletki po Vostochno-Tundrovomu rayonu na periods 1938 goda po 1942 god. (Plan of the third five-year period for Eastern Tundra Rayon from 1938 to 1942.) Central State Archive, fond A-310, opis' 18, delo 137, pp. 103-153.

Razdelishin, L. 1940: Kratkiy ocherk olenevodstva Vostochno- 
tundrovogo rayona Chukotskogo okruga Dal'nevostochnogo kraiya. (Overview of reindeer husbandry of Eastern Tundra Rayon Dal'nevostochnyi Krav.) Central State Archive, fond A-310, opis' 18, delo 419.

Savel'ev, D. V. (ed.) 1971: Severnoe olenevodstvo Evenkii. (Reindeer husbandry of Evenkiya.) Krasnoyarsk: NauchnoIssladovatel'skii Institut Krainego Severa (Scientific Inst. of the Extreme North Publ.).

Semenov-Tien-Shanskiy O. I. 1989: Istoriya severnogo olenya na Kol'skom Poluostrove (History of wild reindeer on the Kola Peninsula). In P. I. Danilov (ed.) Lesnoy severnï olen' (Wild reindeer). Pp. 15-8. Petrozavodsk: Institut biologii.

Shmit, E. V. 1939: Kratkiy ocherk olenevodstva i sobakovodstva
Chaunskogo rayona. (Short outline of reindeer husbandry and dog breeding in Chaunskiy Rayon.) Central State Archive, fond A-310, opis' 18 , delo 331 .

Skogland, T. 1989: Comparative social organization of wild reinder in relation to food, mates and predator avoidance. Berlin: Paul Parey Scientific Publ.

Spiess, A. E. 1979: Reindeer and caribou hunters. An archaeological study. New York: Academic Press.

Ustinov, V. 1956: Olenevodstvo na Chukotke. (Reindeer husbandry at Chukotka.) Magadan: Magadan' Publ.

Vdovin, I. S. 1965: Ocherki istorii $i$ etnografii chukchei. (Historical and ethnographic overview of Chukchi.) Moscow: Nauka Publ. 


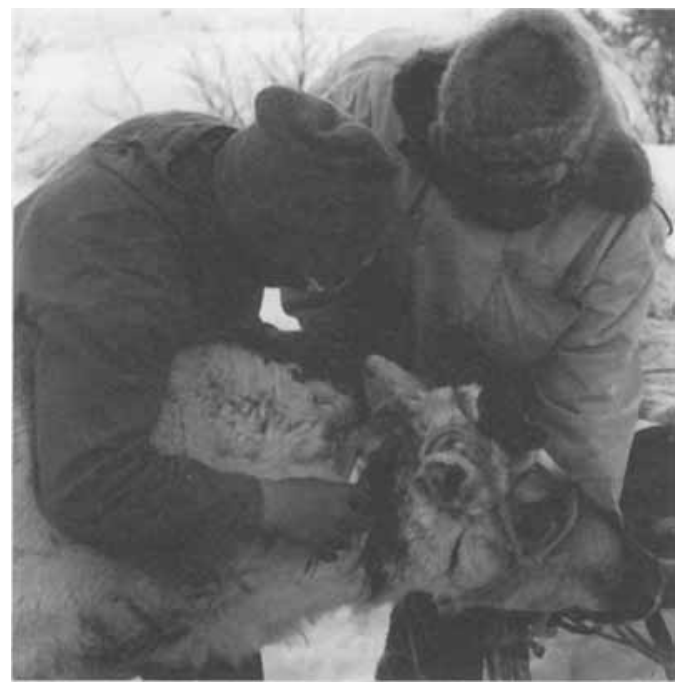

Herders operate on a bruised neck, Tichka Corral Base, Kola Peninsula, May 1998. Reindeer herding cooperative "Olenevod", village of Krasnoshchelye, Kola Peninsula. Photo: Y. Konstantinov.

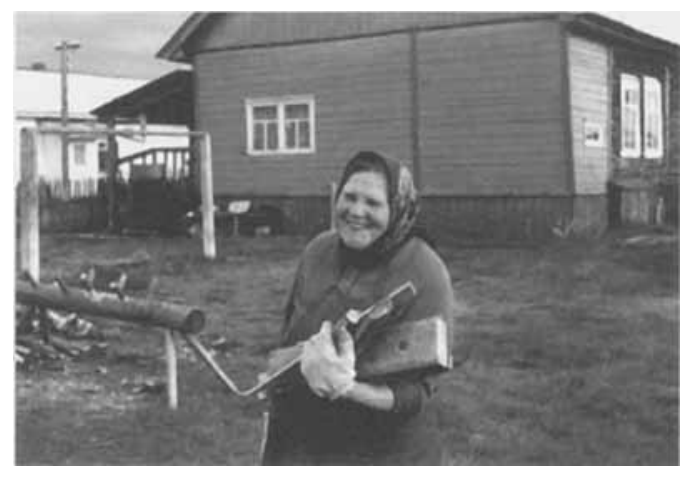

Aunt Zina, village of Krasnoshchelye, Kola Peninsula, June 1998. Photo: Y. Konstantinov.

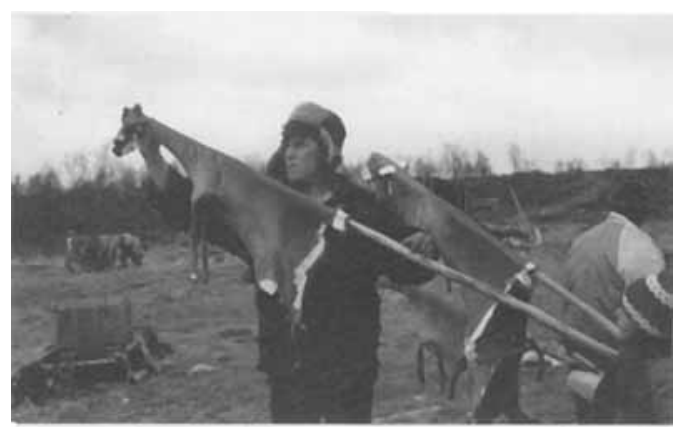

Many new-born calves are trampled in the spring marking corrals. The pelts are used for parka hoods. Tundra camp of Brigade No. 3, "Tundra" Cooperative, Kola Peninsula. Photo: Y. Konstantinov.

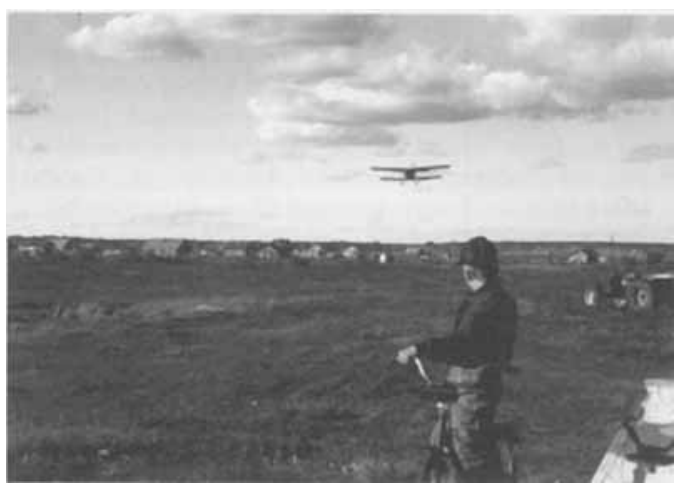

Small airplanes are a rare link with the outside world, village of Sosnovka, Kola Peninsula, July 1996. Photo: Y. Konstantinov.

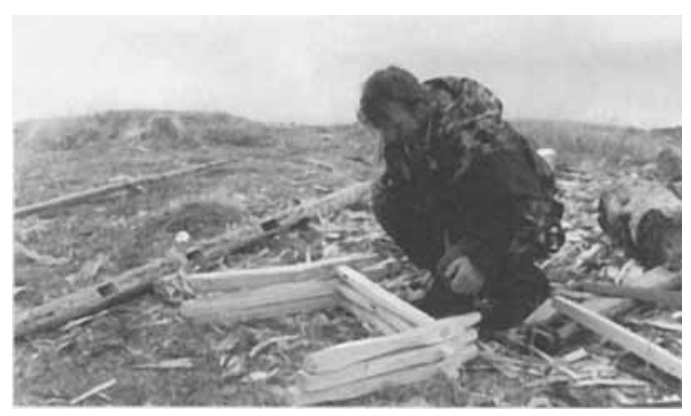

Aligning struts during sled construction, Kola Peninsula. Photo: Y. Konstantinov.

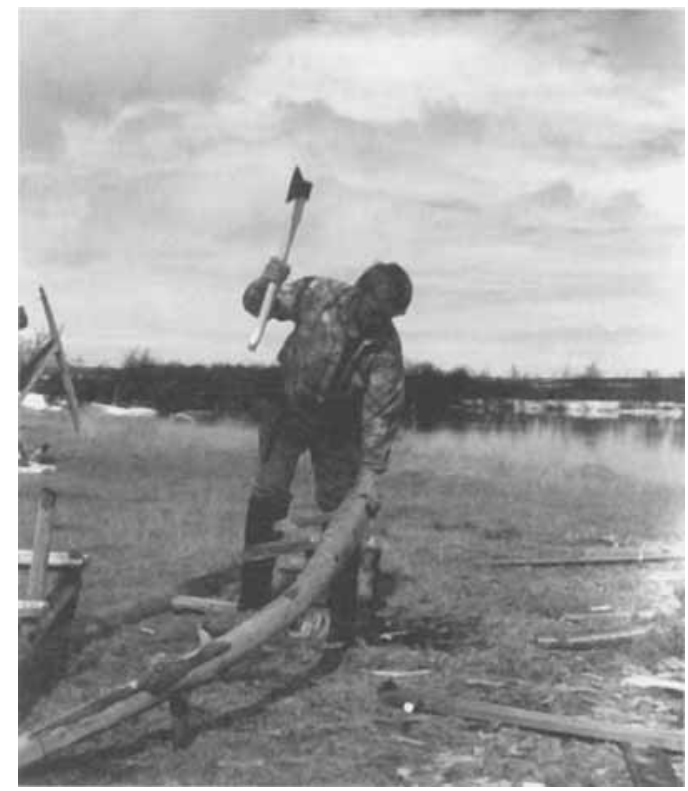

Sled-building by the river Yokanga, Kola Peninsula. Photo: Y. Konstantinov. 